\title{
Jakub Wardęga*
}

\section{Możliwy wpływ doktryny na Biblię na przykładzie Eucharystii}

\section{Wstęp}

W niniejszym artykule chciałbym pokazać kilka przykładów na poparcie tezy, że teologia może mieć wpływ na kształt tłumaczeń Biblii, tj., że niektóre wersety mogły zostać przełożone tak, a nie inaczej, z powodu doktryny panującej w odłamie chrześcijaństwa, który stworzył dane tłumaczenie. Spróbuję zrobić to poprzez porównanie tłumaczeń Biblii przy wzięciu pod uwagę przypisów i kontekstu historycznego.

Na wstępie należy zaznaczyć, że istnieje wiele możliwości tłumaczenia języka greckiego, w którym Nowy Testament został napisany ${ }^{1}$, przez co jest wiele możliwości przełożenia jednego i tego samego wersu. Mimo oddania danego wersetu za pomocą innych słów w różnych przekładach, często nie można jednoznacznie stwierdzić, że dany fragment Biblii został przełożony niepoprawnie. Uzasadnione jest więc założenie, że istniało kilka opcji przekładu lub wyboru tekstów źródłowych. Moja praca będzie próbą pokazania, że doktryna mogła wpłynąć na proces przekładu w taki sposób, że został dokonany przez tłumacza konkretny wybór. Zmiany w Bibliach wydanych przez różne wyznania chrześcijańskie wynikałyby $\mathrm{z}$ istniejących pomiędzy nimi różnic.

\section{Podstawa teoretyczna}

Podstawą teoretyczną moich badań była teoria przekładu wybitnego teoretyka przekładu biblijnego Eugene'a Nidy. W swoim artykule „Principles of correspondence” wyróżnił on tzw. ekwiwalencję „formalną” i „dynamiczną”, stanowiące

Uniwersytet Warszawski, e-mail: jakub.wardega@wp.pl

1 Wniosek wysnuwam na podstawie informacji uzyskanych od ks. dr. Adama Kubisia (KUL) (3 kwietnia 2016, korespondencja osobista). 
granice spektrum różnych typów przekładu literackiego (Nida 2001: 129-130). Krótko opisuję je poniżej.

Tłumaczenie ekwiwalentne formalnie jest wierne tekstowi źródłowemu. Tłumacz podporządkowuje mu w maksymalnym stopniu formę i treść przekładu, czyli np. stara się zachować strukturę języka oraz nie adaptuje tekstu do realiów docelowego odbiorcy. Oznacza to zachowanie zgodności ze źródłem na polu części mowy, długości zdań i zwrotów, budowy i organizacji tekstu, w tym przyporządkowanie pojedynczych słów z języka docelowego słowom z języka źródłowego. Tam, gdzie niemożliwe jest przełożenie wszystkich warstw znaczenia/formy (np. gier słownych, budowy akrostycznej), użyć można przypisów. W pewnych kontekstach są one konieczne, by umożliwić odbiorcy zrozumienie tekstu. Nida (2001: 126-135) zwraca jednak uwagę, że z powodu różnorodności języków nie jest możliwe zawarcie w przekładzie pełni formy i przekazu oryginału.

Przekład ekwiwalentny dynamicznie ma według Nidy wywrzeć na odbiorcę taki wpływ, jaki wywierał na swoich adresatów tekst oryginalny. Stanowi on nowy przekaz informacji w języku docelowym, który ma spełniać - na ile to możliwe - taką samą funkcję, jaką w kontekście pierwotnym miał przekaz pierwotny. Jest on podporządkowany „docelowemu językowi i kulturze, kontekstowi przekazu” i realiom odbiorcy docelowego (Nida 2001: 136). Styl tłumaczenia (włączając słownictwo charakterystyczne dla kontekstu docelowego) ma w tym typie przekładu pierwszeństwo wobec zachowania struktury gramatycznej i nazewnictwa źródła. Nida zaznacza jed nak, że nie jest możliwe całkowite wyeliminowanie obcości tekstu, zwłaszcza przy skrajnej odmienności kultur źródłowej i docelowej. W takich wypadkach tłumacz musi być posłuszny tekstowi źródłowemu. Wśród podanych przez niego przykładów znajdują się efa, faryzeusze i Świątynia Salomona (Nida 2001: 129-137).

W swoim artykule Nida (2001: 127) wysuwa też inną tezę, ważną z punktu widzenia mojego badania, że jednym z czynników istotnych z punktu widzenia różnic w przekładach jest cel, dla którego tłumacz tworzy swoje dzieło: może mieć on kluczowy wpływ na to, jak wiernie zostanie oddany tekst źródła. Jako przykład Nida podaje przypadek języka szylluk, w którym znaczenie terminu „pokuta” wiąże się ze „splunięciem przed kogoś” w sądzie po zakończeniu sprawy „na znak odpuszczenia winy” i uznania kwestii za zakończoną (Nida 2001: 128, 140). Tłumacz chcący przekazać chrześcijańskie znaczenie tego słowa, czyli odwrócenie się od złego postępowania, będzie starał się oddać to w inny sposób (2001: 128).

\section{Podmiot badań}

W toku pracy zająłem się badaniem polskiej katolickiej Biblii Jakuba Wujka, protestanckiej Biblii Gdańskiej oraz porównywałem je z katolicką angielską Biblią Douay-Rheims. Omawiam je pokrótce poniżej. 


\section{Biblia Jakuba Wujka (BJW)}

Jest to tłumaczenie, które było używane (również w wersji uwspółcześnionej) podczas mszy w Kościele katolickim aż do ukazania się pierwszej Biblii Tysiąclecia w 1965 r. - czyli przez ponad 350 lat (Pietkiewicz 2004: 66). Celem przekładu, wyrażonym w samym tytule na pierwszej stronie, była „obrona Wiary swiętey powszechney przeciw kacerztwóm tych czasów należących”. Przekład był więc sam w sobie motywowany dogmatycznie - koniecznością obrony Kościoła katolickiego przed zagrożeniem ze strony protestantów. We wstępie napisano, że stosowano metodę przekładu dosłownego (s. IIII).

Podstawowym tekstem źródłowym była łacińska Wulgata (Wlg). Autorem tłumaczenia był jezuita Jakub Wujek - znający oprócz łaciny także grekę i hebrajski, co pozwoliło mu korzystać również ze źródeł w językach oryginalnych. Tłumacz używał też wcześniejszych tłumaczeń Biblii na polski wydanych przez protestantów. Pierwsze wydanie NT zostało opublikowane w 1593 r.; cała Biblia ukazała się w roku 1599, już po śmierci Wujka (Pietkiewicz 2002: 281-285).

\section{Biblia Gdańska (BG)}

Do czasu wydania obecnie najpopularniejszej Biblii Warszawskiej w 1975 roku był to przekład najczęściej używany przez protestantów - jego historia jest więc w tym aspekcie podobna do historii BJW. Podstawę do tłumaczenia stanowił tekst grecki, który uznano za lepsze źródło niż tekst łaciński (BG 1606: 3-4).

Ponieważ w latach poprzedzających wydanie BG działania kontrreformacyjne zagrażały już Reformacji w Polsce, protestanci podjęli kroki, by z sobą współpracować, aby móc się bronić. Jednym z nich miało być wydanie tłumaczenia Biblii akceptowanego przez każdy odłam protestantyzmu w Polsce. Owocem tych starań była właśnie BG (Pietkiewicz 2002: 303). Celem więc tej publikacji była obrona Reformacji przed Kontrreformacją.

Autorem był Marcin Janicki - pastor zboru reformowanego w Secyminie - który przetłumaczył cały tekst Biblii około roku 1600 . Korektę wykonali Daniel Mikołajewski (kalwini) i Jan Turnowski (bracia czescy). Pierwsze wydanie NT zostało opublikowane w roku 1606, a cała Biblia w 1632. Posiłkowano się m.in. tekstami wydanych wcześniej tłumaczeń protestanckich, NT BJW oraz Wlg (Pietkiewicz 2004: 304-313).

\section{Biblia Douay-Rheims (DV)}

NT został wydany w 1582 r., cała Biblia w 1610 r. Przekład pod wieloma względami bardzo podobny do BJW. Został przetłumaczony $\mathrm{z}$ Wlg, a autorzy mieli również wgląd w teksty w językach oryginalnych i w inne przekłady. Autorzy 
już w samym tytule (który ma kilkadziesiąt słów) zadeklarowali, że to tłumaczenie zgodne z tekstem źródłowym, sporządzone dla obrony doktryny katolickiej (s. 1). Wstępy do obu Biblii mają zbliżoną treść. BJW jest też związana z DV w specyficzny sposób: $\mathrm{z}$ tej drugiej zaczerpnięto część przypisów (Pietkiewicz 2002: 285).

\section{Przedmiot badań}

W badaniu skupiłem się na wersetach, na których opiera się katolicka doktryna o Eucharystii. Jednym z ognisk konfliktu między katolikami a protestantami (i wewnątrz samego protestantyzmu - zob. np. Ziegler [1969, w Lindberg 200o: 121-123]) w epoce Reformacji była kwestia przeistoczenia chleba i wina w tym sakramencie. Każda ze stron miała swoje zdanie, które miało swoje teologiczne implikacje, co pokrótce omówię poniżej. Z uwagi na ograniczoną możliwą objętość artykułu zawrę jedynie opis doktryny uznawanej przez Kościół katolicki oraz Jana Kalwina. Spośród głównych doktryn protestanckich okresu reformacji dotyczących Eucharystii (Lutra, Zwinglego i Kalwina) zdecydowałem się wybrać właśnie tę, ponieważ uważam, że miała najsilniejszy wpływ na ostateczny kształt używanej przeze mnie BG. Nie bez znaczenia jest tutaj fakt, że kongregacja braci czeskich zjednoczyła się ostatecznie z kalwinami.

\section{W Kościele katolickim}

Odnośnie do teologii Eucharystii obecny Katechizm Kościoła katolickiego (2. wyd.) cytuje dokumenty Soboru Trydenckiego:

przez konsekrację chleba i wina dokonuje się przemiana całej substancji chleba w substancję Ciała Chrystusa, Pana naszego, i całej substancji wina w substancję Jego Krwi. Święty Kościół katolicki słusznie i właściwie nazwał tę przemianę przeistoczeniem (KKK 1376).

Pojęcie substancji, jak ją rozumiano $\mathrm{w}$ tamtym czasie, miało swoje korzenie w filozofii Arystotelesa i oznaczało „źródło istnienia” i utrzymanie w nim danego ciała, na które składała się jego „forma” i „materia” (Müller 2015: 708). Metafizyczna filozofia Arystotelesa została zaadaptowana m.in. przez Św. Tomasza z Akwinu na potrzeby zrozumienia Eucharystii i na podstawie zmodyfikowanej jej wersji mogła powstać teologia tego sakramentu, którą zawarto w dokumentach ww. soboru (por. Müller 2015: 708 z Marion 1996: 222).

Podsumowując, w rozumieniu Kościoła katolickiego, w trakcie mszy, po wypowiedzeniu przez księdza formuły poświęcenia nad chlebem i winem, ma miejsce transsubstancjacja (przeistoczenie), która jest zamianą źródła bytu chleba i wina, 
którą wykonuje Bóg. On też decyduje o tym, by przez te właśnie symbole powstała jedność z Chrystusem (Müller 2015: 708).

Aby zaznaczyć kontrast pomiędzy rozumieniem katolickim a kalwińskim, chciałbym zwrócić uwagę na pewną cechę katolickiego rozumienia sakramentu Eucharystii, a mianowicie że po poświęceniu chleb i wino zawierają w sobie „cielesną obecność" Jezusa (Müller 2015: 708). W bardzo obrazowych słowach zostało to ujęte w oświadczeniu wydanym podczas synodu laterańskiego:

[...] chleb i wino znajdujące się na ołtarzu po konsekracji są [...] prawdziwym ciałem i krwią naszego Pana Chrystusa, które są [...] dotykane i dzielone rękoma kapłanów oraz przeżuwane i rozcierane zębami wiernych (DH 690 w Müller 2015: 706).

Reasumując, w katolickim rozumieniu Eucharystii całość natury chleba i wina, przemiana eucharystyczna oraz będąca jej wynikiem tzw. „cielesna obecność" Ciała i Krwi Jezusa po konsekracji zawierają się całkowicie w wymiarze fizycznym (zob. Müller 2015: 709).

\section{Według Kalwina}

Jan Kalwin nauczał, w odróżnieniu od Kościoła katolickiego, że sakrament Eucharystii (przez protestantów nazywany Wieczerzą Pańską) składa się z „fizycznych znaków [...] i duchowej prawdy, która jest przez same symbole okazywana i o której te symbole zaświadczają" (1960: 1371). Tak jak fizyczne chleb i wino są pokarmem dla ciała, tak Ciało i Krew Jezusa są pokarmem dla duszy. Z tego wynika, że transsubstancjacja jest fikcją (zob. też Kronenfeld 1998: 44). (Kalwin 1960: 1370-1374).

Innymi słowy w kalwińskim rozumieniu istnieją $\boldsymbol{d} \boldsymbol{w} \boldsymbol{a}$ wymiary, w których zawiera się Wieczerza Pańska - fizyczny i duchowy. Ciało i Krew Chrystusa nie są fizycznie obecne w sakramencie.

Podobnie jednak jak w Kościele katolickim, nie da się stwierdzić tego na podstawie obserwacji. Według Kalwina funkcją symbolu, który człowiek widzi, jest upewnienie o istnieniu daru, którego nie widzi; spożywając namacalne symbole, chrześcijanie powinni wierzyć, że otrzymali jednocześnie również Ciało, które one oznaczają (1960: 1371).

\section{Wyniki badania}

Na podstawie analizy wstępów przyjąłem, że twórcy zarówno BJW, BG, jak i DV, starali się tłumaczyć z zastosowaniem ekwiwalencji formalnej. W badaniu zdecydowałem się sprawdzić, czy obrany przez autorów BJW cel - obrona doktryny 
katolickiej - mógł spowodować, że tłumacz odstąpił od obranej przez siebie strategii ekwiwalencji formalnej, co mogłoby spowodować konkretne decyzje translatorskie. Moją tezą było, że jest możliwe wskazanie miejsc, co do których można z dużym prawdopodobieństwem przypuszczać, że tak się stało.

Podczas badania przyglądałem się 68 wersetom w Biblii, na których głównie oparta jest doktryna o Eucharystii: Ew. Mateusza 26, 26-29; Ew. Marka 14, 22-25; Ew. Łukasza 22, 15-20; Ew. Jana 6, 22-71 i 1 List Św. Pawła do Koryntian 11, 23-26 (Müller 2015: 696). Ważnym źródłem były też dla mnie komentarze egzegetyczne zamieszczone w BJW. Przykłady, które uważam za świadectwo wpływu doktryny na tłumaczenie, przedstawiam poniżej.

Ewangelia Mateusza 26, 28

BG: „Abowiem toć jest krew moja nowego Testamentu, która się za wielu wylewa na odpuszczenie grzechów".

BJW: „Abowiem ta jest krew moia nowego testamentu, która za wielu będzie wylana na odpuszczenie grzechów”.

W cytowanym powyżej wersecie zaznaczyłem fragment, który w BG i w BJW różni się użyciem gramatycznego czasu i strony: w BG został użyty czas teraźniejszy i strona czynna, a w BJW czas przyszły i strona bierna. Co jednak ważne, przypis obok tekstu BJW mówi, że w oryginalnym tekście greckim użyty został czas teraźniejszy, „skąd znać, że p. Iesus na ostatniey wieczerzy, wylewając za nas krew Swoię, Bogu Oycu ofiarował [...]” (s. 1149). Osobny przypis na końcu rozdziału pokazuje też, że w grece jest strona czynna i że takie brzmienie tego wersu jest zgodne z katolicką doktryną.

Uważam, że świadczy to o wpływie doktryny na przekład: mimo zgodności tekstu w języku oryginalnym z teologią Kościoła katolickiego w zapalnej kwestii, jaką była Eucharystia, tłumacz przełożył werset z łacińskiej Wlg. Stało się tak, ponieważ Kościół katolicki na soborze trydenckim uznał jej tekst za „autentyczny” (1546, sesja IV), bo od dawna była ona obowiązującym tłumaczeniem - i właśnie te argumenty są wymienione w pierwszej kolejności w przedmowie do BJW jako uzasadnienie pozycji Wlg w Kościele (s. IIII). Nie chodziło tu jednak o zakwestionowanie wagi manuskryptów w językach oryginalnych (Crehan 1963: 204). Sobór jednak jasno stwierdził, że nikt nie miał prawa kwestionować jej autorytetu. BJW została więc przetłumaczona z łaciny, a gdziekolwiek została stwierdzona ważna odmienność od tekstów w językach oryginalnych, podawano je w przypisach (s. IIII). Powyższy werset jest więc przykładem określonej tendencji.

\section{Ewangelia Jana 6, 53}

BG: „Rzekł im tedy Iezus: Zaprawde, Zaprawde wam powiadam, jeśli nie będziecie ieść ciała Syna człowieczego, y pić krwie iego, nie macie żywota w sobie”. 
BJW: „Rzekł im tedy Jesus: Zaprawdę, zaprawdę wam powiadam: Jeśli byście nie iedli ciała Syna człowieczego, y nie pili krwie iego, nie będziecie mieć żywota w sobie”.

Zaznaczone w wersie słowa „nie macie/nie będziecie mieć”, są w BG w czasie teraźniejszym, a w BJW w przyszłym, przy czym przypis w BJW wyjaśnia, że tekst grecki brzmi „nie macie”2 (s. 1240), tak jak później zostało to napisane w BG. Uważam, że zastosowana w tym miejscu strategia tłumaczenia $\mathrm{z}$ łaciny mogła zapobiegać wzbudzaniu kontrowersji, dostosowując wers do aktualnie wtedy obowiązującej doktryny, głoszącej, że przyjmowanie Eucharystii nie jest nieodzowne do zbawienia człowieka.

Tutaj muszę odwołać się do kontekstu historycznego: w V w. (417 r.) interpretacja tego wersu jako „jeśli nie przyjmiesz Eucharystii, nie masz życia w sobie”3 została przez papieża Innocentego I użyta do uzasadnienia ${ }^{4}$ „konieczności udzielania [Eucharystii] niemowlętom"5, bez której nie mogły mieć udziału w zbawieniu (Reynolds c. 1890: 269). Przez kilkaset lat była to obowiązująca doktryna. Z czasem jednak stanowisko Kościoła zmieniło się ${ }^{6}$, co potwierdził m.in. Sobór Trydencki, uznając, że „[m]ałe dzieci niemające jeszcze pełnego używania rozumu, z żadnego względu nie są zobowiązane do przyjmowania Komunii”, ponieważ do tego czasu wystarcza im do zbawienia „nieutracalna łaska chrztu” (Müller 2015: 717). Negatywne stanowisko przyjęli także protestanci (Reynolds c. 1890: 269).

Uważam, że zaistnienie zmiany doktryny oraz chęć Kościoła katolickiego odcięcia się od nieuznawanego7 jej brzmienia mogły odcisnąć swoje piętno również na BJW. Chciałbym zwrócić uwagę, że zastosowanie w drugiej części zdania czasu przyszłego odsuwa perspektywę zdania od teraźniejszości, przez co trudniej je zinterpretować tak, jak to robił Innocenty I. Efekt ten wzmacniany jest dodat-

2 Tekst grecki można tu przełożyć na polski również w czasie przyszłym: „nie będziecie mieć” - jak udało mi się ustalić podczas konsultacji z dr. Janem Kozłowskim (UW). Autor BJW nie wspomina jednak o tym.

3 "[E]xcept you receive the Eucharist, you have no life in you".

4 Zob. Jurgens 1979: 182; Bingham 1844: 798.

5 "The necessity of communicating infants".

6 Obszerniejszy opis dziejów tej doktryny aż do czasów nowożytnych zawarto w Bingham 1844: 797-800.

7 Uważam, że o chęci odsunięcia się Kościoła katolickiego od tej doktryny świadczyć może fakt, że w NT DV werset J. 6, 53, opatrzony jest wprowadzającym w błąd (zob. Bingham 1844: 797798 i Reynolds, c. 1890: 269) przypisem (s. 236-237) odwołującym się również do dokumentów Soboru Trydenckiego (sesja XXI, doktryna o Komunii Św., rozdz. IV), gdzie jest mowa, że Kościół nigdy nie stał na stanowisku, że spożywanie Eucharystii jest konieczne do zbawienia i że to jedynie protestanci źle zrozumieli św. Augustyna (który również wypowiadał się na ten temat, przynajmniej po części, podzielając opinię Innocentego I - por. Schaff 1887: 28 i Reynolds, c. 1890: 268). 
kowo przez użycie w pierwszej części zdania w BJW trybu przypuszczającego, co bardziej jeszcze osłabia akcent na tu i teraz. Co ważne jednak, w pierwszej części tego zdania w NT DV nie został użyty tryb przypuszczający, lecz fraza „[j]eśli nie będziecie jeść ciała Syna człowieczego i pić krwi jego...”" z z czego wynika, że użycie tego trybu mogło nie być koniecznością w przekładzie. Uważam też, że tego sposobu przetłumaczenia w BJW nie można uzasadnić dbałością autorów o stylistykę języka polskiego, ponieważ sami stanowczo podkreślili, że pierwszeństwo względem stylu miała dla nich dbałość o wierność przekładu (s. IIIIn.).

\section{Wnioski}

Jednym z wniosków płynących z moich rozważań może być stwierdzenie, że doktryna Kościoła w pewnym stopniu może wpłynąć na tekst tłumaczenia Biblii. Trzeba jednak przyznać, że rozważania takie jak powyższe z konieczności są do pewnego stopnia subiektywne. Skupiłem się tutaj na pokazaniu wpływu doktryny na przekład katolicki, dobrze znane są jednak pewne przykłady takiego wpływu również po stronie protestanckiej, np. tzw. Comma Johanneum obecna w BG, BJW i DV (dziś uznawana za nieautentyczną). Problem ten może dotyczyć większej liczby wersetów. Przyszłe badania mogą więc skupić się na znalezieniu i opisaniu w Bibliach wydanych w różnych odłamach chrześcijaństwa innych jeszcze miejsc w Biblii noszących ślady oddziaływania doktryny na tłumaczenie.

\section{Bibliografia}

Bingham J., 1844, The antiquities of the Christian Church, Henry G. Bohn, London.

Calvin J., 1960, Institutes of the Christian religion, The Westminster Press, Philadelphia.

Crehan F.J., 1963, The Bible in the Roman Catholic Church from Trent to the present day, [w:] S.L. Greenslade (red.), The Cambridge history of the Bible: volume three

- the West from the Reformation to the present day, Cambridge University Press, s. 199-237.

Jurgens W.A., 1979, The faith of the early fathers: volume three - a sourcebook of theological and historical passages from the writings of Saint Augustine to the end of the Patristic Age, The Liturgical Press, Collegeville.

8 „Vnles you eate the flesh of the Sonne of man, and drinke his bloud, you shal not haue life in you". Możliwe, że, jeśli założyć celową chęć odsunięcia się od wspomnianej doktryny, rolę trybu przypuszczającego mógł spełniać przypis wspomniany w adnotacji 7. 
Kronenfeld J., 1998, King Lear and the naked truth: rethinking the language of religion and resistance, Duke University Press, Durham and London.

Lindberg C. (red.), 2000, The European reformations sourcebook, Blackwell Publishers, Oxford.

Marion J.L., 1996, Bóg bez bycia, Znak, Kraków.

Müller G.L., 2015, Dogmatyka katolicka, WAM, Kraków.

Nida E., 2001, Principles of correspondence, [w:] L. Venuti \& M. Baker (red.), The Translation Studies reader, Routledge, London and New York, s. 126-140.

Reynolds H.R., c. 1890, The pulpit commentary: the Gospel of John, Funk \& Wagnalls Company, New York and Toronto.

Schaff P. (red.), 1887, A select library of the Nicene and Post-Nicene fathers of the Christian Church: volume five - Saint Augustin: anti-Pelagian writings, The Christian Literature Company, New York.

\section{Przekłady Biblii}

The English College at Dovvay, 1635, The Holy Bible, Iohn Covstvrier, Reuen.

Novvy Testament pana naszego Jezusa Chrystusa, 1606, Drukowano u Wdowy Guilhelma Guilmothana, Gdańsk.

Wujek J., 1599, Biblia to iest ksiegi Starego y Nowego Testamentv, Drukarnia Łazarzowa, Kraków.

\section{Netografia}

Baranowski M. (oprac.), [bdw], Katechizm Kościoła katolickiego, http://www.katechizm.opoka.org.pl/rkkkII-2-1.htm (dostęp: 23.02.2017).

The Council of Trent 1542-1564, The canons and decrees of the Council of Trent, http:// www.ewtn.com/library/COUNCILS/TRENT.ZIP (dostęp: 9.05.2016).

Pietkiewicz R., 2004, Biblia Tysiaclecia $w$ tradycji polskiego edytorstwa biblijnego, rozprawa doktorska, Papieski Wydział Teologiczny we Wrocławiu, http://digital. fides.org.pl/dlibra/doccontent?id=730 (dostęp: 9.05.2016).

Pietkiewicz R., 2009 (2002), Pismo Święte w języku polskim w latach 1518-1638: sytuacja wyznaniowa w Polsce a rozwój edytorstwa biblijnego, rozprawa doktorska, Uniwersytet Wrocławski, http://digital.fides.org.pl/dlibra/docmetadata?id=728\&dirds $=1 \& \mathrm{tab}=2$. 
Jakub Wardęga

\section{How Church doctrine could influence the Bible - a case study of Bible verses concerned with Eucharistic theology}

Summary

The aim of the article is to show that the wording of certain verses in Bible translations may have been shaped to suit the doctrine of those branches of Christendom which produced these translations. This will be done with the use of versions of certain of the verses from the New Testament to which relates the Catholic doctrine of the Eucharist, as the form and meaning of these verses have been battlegrounds of a theological struggle between Catholics and Protestants - most violent during the time of the Protestant Reformation. In the research I used two most important Polish translations of the New Testament made in the age of the Reformation: the Protestant Biblia Gdańska (1606) and the Catholic Biblia Jakuba Wujka (1599).

Keywords: doctrine; Eucharist; Bible; translation; Reformation; Counterreformation.

\section{Możliwy wpływ doktryny na Biblię na przykładzie Eucharystii}

Streszczenie

Celem artykułu jest pokazanie, że sformułowanie pewnych wersetów w przekładzie Biblii mogło być dostosowane do doktryny tego odłamu chrześcijaństwa, z którego dane tłumaczenia się wywodzą. W tym celu porównane zostaną różne wersje niektórych spośród 68 wersetów Nowego Testamentu, na których opiera się doktryna o Eucharystii. Eucharystia była jednym z zagadnień, które budziły spory między katolikami a protestantami, zwłaszcza w czasie Reformacji protestanckiej. W trakcie badań wziąłem pod uwagę najważniejsze przekłady Nowego Testamentu pochodzące z okresu Reformacji: protestancką Biblię Gdańską z 1606 roku i katolicką Biblię Jakuba Wujka z 1599 roku.

Słowa kluczowe: doktryna; Eucharystia; Biblia; przekład; Reformacja; Kontrreformacja. 